\title{
Impact of National Economic Empowerment and Development Strategy (NEEDS) on the Private Sector: A Case Study of Power Sector
}

\author{
Modinat O. Olusoji (Corresponding author) \\ School of Postgraduate studies and Consulting \\ Centre for Management Development \\ Management Village, Shangisha, Lagos
}

Olusegun O. Oloba ${ }^{1}$

Economic Management Department

Centre for Management Development

Management Village, Shangisha, Lagos

Accepted: July 25, 2014

Doi:10.5296/ jpag.v4i3.5834 URL: http://dx.doi.org/10.5296/ jpag.v4i3.5834

\begin{abstract}
The paper examines the impact of the National Economic Empowerment and Development Strategy (NEEDS) on the private sector by looking at the contribution the power sector had made in realizing the goal of making private enterprise the engine of growth in Nigeria. NEEDS reform is to transform the power sector into one led by the private sector, with the role of government restricted primarily in policy formulation and establishment of an appropriate legal and regulatory framework. The paper discusses among many things: an overview of power supply in Nigeria; the effect of power sector on private sectors; challenges of the sector; as well as the ways forward. The paper concludes that there is need to put concerted effort to generate adequate power supply to enable the private sector thrives and serves as engine of growth in Nigeria.
\end{abstract}

Keywords: NEEDS, private sector, power sector, Nigeria

\footnotetext{
${ }^{1}$ Dr (Mrs.) M. O. Olusoji and Mr. O. Oloba work with the Centre for Management (CMD), Lagos, Nigeria as at the time of writing this paper. Mr.O. Oloba is deceased while Dr.(Mrs.) M.O. Olusoji is still in CMD.
} 


\section{Introduction}

The aspiration of Nigeria is league of the 20 leading economies in the World by the year 2020 . This aspiration is based on the realization that the country is endowed with material and human resources, thereby places her in good position to achieve greatness. Harnessing these resources is expected to create a significant improvement in business opportunities in the nation's economy through implementation of the National Economic Empowerment and Development Strategy (NEEDS).

The goal of NEEDS is to reduce poverty in Nigeria and this can materialise only if the various sectors are thriving. One of the pillars of NEEDS is promoting private enterprise. Its essence is seeing the private sector as the engine of growth.

One of the pre-requisites of increased production is abundance of energy i.e. electricity which is mainly utilized for driving machines for the production of various items. The private sector stakeholders have always emphasized in their public policy advocacy, the need for improvement in infrastructure, particularly, electricity which is the primary energy required for production.

Power is a strategic sector, which represents the most important infrastructure requirement for driving the private sector. However, Ngeria's power system is so inadequate that it has held back economic progress and social wellbeing.

NEEDS envisions reforms that will transform the power sector into one led by the private sector, with the role of government restricted primarily in policy formulation and establishment of an appropriate legal and regulatory framework. The purpose of this paper is to discuss the impact of NEEDs on the private sector and by looking at the contribution the power sector had made in realizing the goal of making private enterprise the engine of growth in Nigeria. Following the introduction is the NEEDS policy thrust and target for power sector in section 2. Section 3 discusses the contribution of sector to the achievement of NEEDS. Section 4 presents an overview of power supply in Nigeria while section 5 examines the effect of the power sector performance on the private sector. Section 6 discusses the challenges and way forward while section 7 concludes the paper.

\section{NEEDS Policy thrust and targets for power Sector.}

NEEDS proposes the following targets for the power sector to meet before 2007:

- Increase generation capacity from 4,200 MW to 10,000 MW (an increase of 138 percent).

- Increase transmission capacity from 5,838 megavolt amperes (MVA) to 9,340 MVA, a 60 percent increase.

- Increase distribution capacity from 8,425 MVA to 15,165 MVA (an increase of 80 percent).

- Increase tariff collections from 70 percent to 95 percent. 
- Reduce transmission and distribution losses from 45 percent to 15 percent.

- Reduce controllable costs by at least 30 percent.

- Rightsize to reduce staff strength by about 15 percent.

- Create 11 semiautonomous business units (profit centers). (This target was met in January 2004.)

- Make the transmission company a semiautonomous unit by April 2004.

- Unbundle generation by the fourth quarter of 2004.

The electricity supply industry is capital intensive and cannot be funded adequately by the federal government alone. The sector therefore needs to be reformed in order to attract private sector participation

\section{Contribution of sectors to the achievement of NEEDS}

We shall now examine various prominent sectors in the Nigeria economy from 2001 to 2007:

Table 1: Gross Domestic Product by Economic Activity for Different Sectors of the Economy (Percentage Distribution)

\begin{tabular}{|l|l|l|l|l|l|l|l|}
\hline SECTORS & $\mathbf{2 0 0 1}$ & $\mathbf{2 0 0 2}$ & $\mathbf{2 0 0 3}$ & $\mathbf{2 0 0 4}$ & $\mathbf{2 0 0 5}$ & $\mathbf{2 0 0 6}$ & $\mathbf{2 0 0 7}$ \\
\hline Agricultural & 42.30 & 42.14 & 41.02 & 40.99 & 40.99 & 41.73 & 42.08 \\
\hline Mining \&Quarrying & 26.43 & 23.83 & 26.89 & 26.10 & 24.65 & 22.26 & 20.00 \\
\hline Manufacturing & 3.39 & 3.59 & 3.46 & 3.57 & 3.67 & 3.78 & 3.88 \\
\hline $\begin{array}{l}\text { Utilities } \\
\text { Transportation }\end{array}$ & 2.98 & 3.64 & 3.44 & 3.58 & 3.58 & 3.54 & 3.47 \\
\hline $\begin{array}{l}\text { Post\& } \\
\text { Telecommunication }\end{array}$ & 0.55 & 0.78 & 0.98 & 1.20 & 1.46 & 1.83 & 2.30 \\
\hline $\begin{array}{l}\text { Banks and other } \\
\text { financial institutions }\end{array}$ & 4.15 & 5.03 & 4.24 & 4.08 & 3.94 & 3.90 & 3.85 \\
\hline
\end{tabular}

Source: CBN Statistical Bulletin Vol. 17, December 2006 \&Vol. 18, December 2007

From the table above, looking at the major key sectors of the economy we can deduce that GDP for Agricultural sector (which comprises crop production, live stocks, forestry and fishing) fell from 42.30 in 2001 to 42.14 percent in 2002. It fell further to 41.02 and 40.99 percent in 2003 and 2004 respectively. Despite the introduction of NEEDS, there had not 
been much improvement. It increased to 41.7 in 2006 and stood at 42.08 percent in 2007 . In the Mining and Quarrying sector (which has coal mining, crude petroleum and natural gas, metal ores and quarrying and other mining, and oil refinery) the GDP moved from 26.43 in 2001 to 26.89 percent in 2003 but dropped 26.10 in 2004, 24.65 in 2005, 22.26 in 2006 and 20 percent in 2007. The GDP of Manufacturing sector (cement and other manufacturing) increased from 3.39 in 2001 to 3.59 percent in 2002 then dropped to 3.46 in 2003 but rose to 3.57 in 2004, 3.78 in 2006 and 3.88 percent in 2007.

Concerning the Utilities sector (electricity and water), the GDP for 2001 which was 2.98 rose to 3.64 percent in 2002 but fell to 3.44 percent in 2003. It however rose marginally to 3.58 in 2004 but fell to 3.54 in 2006 and 3.47 per cent in 2007. The GDP for Transportation sector (road transport rail transport and pipelines water transport, air transport and transport services) were $2.56,2.89,2.67,2.65,2.65,2.67$ and 2.68 percent in 2001, 2002, 2003, 2004, 2005, 2006 and 2007 respectively. The GDP for Post and Telecommunication sector (telecommunications and post) was $0.55 \%$ in 2001 but moved up to $0.78 \%$ and $0.98 \%$ in 2003 and 2003 respectively. It increased further to 1.2 percent in 2004, 1.83percent in 2006 and 2.30percent in 2007. Finally, the GDP of Banks and other financial institutions (financial institutions and insurance) were 4.15, 5.03, 4.24, 4.08 and 3.94percent for 2001, 2002, 2003, 2004 and 2005 respectively. It however fell to $3.90 \%$ in 2006 and fell further to $3.85 \%$ in 2007.

\section{An Overview of Power Supply in Nigeria}

Regular power supply is the prime mover of technological and social development. There is hardly any enterprise or indeed any aspect of human development that does not require energy in one form or the other. Nigeria is richly endowed with various energy sources such as crude oil, natural gas, coal, hydropower, solar energy, fissionable materials for nuclear energy. Yet the country consistently suffers from energy shortage - a major impediment to industrial and technological growth.

The National Electric Power Authority (NEPA), a government parastatal, has the sole responsibility for managing the generating plants as well as distribution of power nationally. The total generating capacity is about $3000 \mathrm{MW}$, approximately thrice the current level of national demand. However, the actual power available at any given time is less than 40 percent of the total capacity due to poor maintenance, neglect by past governments, financial inadequacy, corruption among others; hence there is a perennial shortage. This situation is aggravated by a grossly inefficient, poorly maintained distribution system. Industry can only cope with power outages by resorting to internal generating plants (Ajanaku 2007; Adegbamigbe 2007).

However, when electricity goes on and off five times in an hour, this creates serious problems for manufacturing and industrial sectors. Equipment is damaged by power surges that usually accompany epileptic power supply and goods at various stages of manufacturing are damaged. Industry's response has been to run permanently on internal generating plants and use NEPA supply as standby. It is ironical that, in spite of the enormous power generation potential, about 60 percent of the country still has no access to electric power supply (UNDP 2001; 
Ajanaku 2007; Adegbamigbe 2007).

Table 2: Comparative analysis of consumption of electricity worldwide

\begin{tabular}{|c|c|c|c|}
\hline Country & Population & Power Generation & Per Capita Consumption \\
\hline United States & 250.00 Million & $813,000 \mathrm{MW}$ & $3.20 \mathrm{KW}$ \\
\hline Cuba & 10.54 Million & 4,000MW & $0.38 \mathrm{KW}$ \\
\hline United Kingdom & 57.50 Million & 76,000MW & $1.33 \mathrm{KW}$ \\
\hline Ukraine & 49.00 Million & $54,000 \mathrm{MW}$ & $1.33 \mathrm{KW}$ \\
\hline Iraq & 23.60 Million & $10,000 \mathrm{MW}$ & $0.42 \mathrm{KW}$ \\
\hline South Korea & 47.00 Million & $52,000 \mathrm{MW}$ & $1.09 \mathrm{KW}$ \\
\hline South Africa & 44.30 Million & $45,000 \mathrm{MW}$ & $1.015 \mathrm{KW}$ \\
\hline Libya & 5.50 Million & $4,600 \mathrm{MW}$ & $1.015 \mathrm{KW}$ \\
\hline Egypt & 67.90 Million & $18,000 \mathrm{MW}$ & $0.265 \mathrm{KW}$ \\
\hline Nigeria & 140.00 Million & 4,000MW & $0.03 \mathrm{KW}$ \\
\hline
\end{tabular}


Source: Agbo (2007)

Table 2 shows a comparative analysis of consumption of electricity worldwide. Based on the table for instance, Libya with a population of only 5.5 million has generating capacity of 4,600 megawatts, approximately the same as Nigeria which has a population of about 140 million (Lohor and Ezeigbo 2006; Oloja and Oretade 2006). Nigeria has the least per capita consumption among the countries listed. Even a country like Libya has higher per capita consumption than Nigeria. There are plans to build seven more plants in Nigeria (Atser 2007). All the stations are oil or gas fired and the country is selling power to other African countries. South Africa with a population of only 44.3million has a generating capacity of 45,000 megawatts, almost eleven times the generation capacity in Nigeria which has three times the population of South Africa (Agbo 2007). Studies and experiences have shown that power generation in the country is discouraging and incomparable with what obtains in smaller African countries.

The survey on power distribution to the industrial sector in Nigeria showed that average power outage in the industrial sector increased from 13.3hours in January 2006 to 14.5 hours in March 2006. In a worsening experience, the outage increased to 16.48 hours per day in June. In other words, power distribution in the month of June, 2006 to the industrial sector, on the average, was 7.52 hours per day (Odiaka 2006).

In Sharada/Challawa industrial area in Kano, the outage increased from 15.4 hours in January, 2006 to 17.6 hours in March of the same year. In Bompai area in Kano State, power outage increased from 10.3 hours in January to 13.0 hours in March, while in Enugu/Anambra zone it increased from 17.2 hours to 18.5 hours within the same period. In Edo/Delta zone the average power supply to industrial area is put at 4.4 hours per day. The Ikeja industrial area of Lagos enjoyed power supply for 12.5 hours per day, the highest in the country so far . Industrial estates in Bauchi, Benue and Plateau zones receive power supply for 4.5 hours per day which amounted to near blackout in real sense (Nwaoshai 2006; Odiaka 2006).

Studies further revealed the power supply in virtually all the sates in Nigeria has been very dismal. For instance, in Benue State, only Makurdi the state capital receives electricity supply for about five hours a day. Moreover, in Delta State some communities never had power supply for more than six months. In Lagos, the commercial nerve centre of the country, the situation is also bad as power supply in many residential parts of Lagos is about four hours per day with cuts at short intervals. It is a total black out in some areas for about three days or more (Akpan 2005; Odiaka 2006; Ogunmodede 2006).

In recognition that the problem of power supply is a challenging one scuttling socio-economic activities across the country, the civilian administration in Nigeria since its advent in 1999 started making huge investments in the energy sector. Available records showed that by the end of 2001 the generating capacity had increased from 1824 MW (from 19 generating units) in March 2000, to about 4000MW (from 40 generating units) and a new peak generation of $2934 \mathrm{MW}$ was recorded in the process. This was made possible through rehabilitation of existing generating units, installation of new generating plants and the procurement of power from independent operators (Makoju 2002; Adegbamigbe 2007; Agbo 
2007).

In the area of transmission, efforts were made to extend and reinforce the transmission grid through the construction of 14 transmission lines (and associated sub station) and the reinforcement of 26 substations. In view of the fragile nature of the grid, an additional 23 lines and 33 substations were executed in 2002. The primary objective was to extend the grid and transport bulk power supply to areas not adequately covered by the then existing transmission network. In the area of distribution, available NEPA records showed that the distribution network undertook the deployment and installation of;

- One hundred and thirty six 15 MVA 33/11 KV power transformers and associated equipment nationwide ;

- Fifty two 7.5 MVA 33/11 KV power transformer and associated equipment nationwide; and

- Various sizes of distribution transformers and equipment nationwide (Makoju 2002; Ajanaku 2007).

In all, 1191 projects were completed by 2001. These comprised of 267 injection sub-stations projects and 924 distribution sub-station projects. Also 346 transformers were locally procured and allocated for replacement of units lost in circuit, to ensure prompt restoration of supply to affected customers. Other materials and equipment for network maintenance such as transformer oil, conductors and cables, test and safety equipment, work vehicles, communication equipment etc. were also procured and distributed to various parts of the country (Makoju 2002). In the recent times, the Authority had embarked on a number of special projects geared towards increased involvement of the private sector as a necessary ingredient for long-term sector viability. It was expected that these projects would not only improve the overall electricity power situation in Nigeria, but should instill in the authority practices which would be invaluable in deregulated energy sector (Agbo 2007).

These initiatives arose out of the basic realisation that government is increasingly becoming unable to fund this heavily capital intensive sector. For instance, The Rehabilitate Operate and Transfer (ROT) programme for Sapele and Afam power stations is an attempt by government to get AES Frontiers Limited and Shell Petroleum Development Company Ltd respectively- private sector - to invest and participation in provision of power. With this, it is expected the about $\$ 700$ million of private capital would be injected in the rehabilitation/modernisation of both power stations over a period of time (Johnson 2007).

In addition an Operation and Maintenance $(\mathrm{OM})$ programme was conceptualised to provide improved technical and managerial expertise at power stations via the introduction of short-term private participation especially in stations such as Delta, Egbin, Jebba, Shiroro and Kanji. Since improved generation can only be sustained by corresponding improvements in revenue generation;the Authority sought and received approval for the outsourcing of parts of its marketing activity in a limited number of districts under the Revenue Cycle Management (RCM). Given the paucity of funds for electricity, infrastructure rehabilitation and expansion, the Authority sought for and received approval from the World Bank for \$100 million credit 
under very concessionary terms (Makoju 2002; Agbo 2007).

Table 3: Old Power Plants and Generation Capacities

\begin{tabular}{|l|l|l|l|l|}
\hline Station & Type & $\begin{array}{l}\text { Inauguration } \\
\text { date }\end{array}$ & $\begin{array}{l}\text { Installed } \\
\text { capacity MW }\end{array}$ & $\begin{array}{l}\text { Current output } \\
\text { MW }\end{array}$ \\
\hline Oji & Thermal & 1956 & 30 & - \\
\hline Delta & Thermal & $1966-1999$ & 900 & 366 \\
\hline Ijora & Thermal & 1978 & 60 & - \\
\hline Sapele & Thermal & $1978-1981$ & 1,020 & 62 \\
\hline Kainji & Hydro & $1968-1978$ & 760 & 445 \\
\hline Jebba & Hydro & $1983-1984$ & 578 & 339 \\
\hline Afam & Thermal & $1978-1982$ & 969 & 85 \\
\hline Egbin & Thermal & $1985-1987$ & 1320 & 241 \\
\hline Shiroro & Hydro & $1989-1990$ & 600 & $\mathbf{6 2 3 7 . 4}$ \\
\hline Total & & & & \\
\hline
\end{tabular}

Source: Atser (2006) and Agbo (2007).

The current nation's energy demand is estimated at 10000MW. However, existing power stations and their installed capacities as shown on Table 3 are: Oji Thermal Station, Enugu State (30MW); Delta Thermal, Delta State (900 MW); Ijora Thermal Lagos State (60MW); Sapele Thermal, Delta State(1020 MW); Kainji Hydro Station, Niger State (760 MW); Jebba Hydro Station, Niger State (578.4MW); Afam Thermal, Rivers State (969); Egbin Thermal, Lagos State (1320MW) ; and Shiroro Hydro, Niger State (600MW).

With the installed capacity of about $6000 \mathrm{MW}$, the country manages to generate only a meagre (of more or less) $4000 \mathrm{MW}$ of electricity (Atser 2006). The current per capita consumption of electricity in Nigeria is about $106 \mathrm{KWh} /$ person compared to Ghana's 430, India's 470 or Brazil's 1800. Expected increase in consumption is $379 \mathrm{MW}$ annually at 2.5 percent population annual growth rate and five percent annual growth of the economy. Available records showed that government has set 10000 MW target to be achieved by the end 2007 as it has invested in new power projects that would be privatised after completion (Owan 2005). However, it is instructive to note that these huge investments have not improved the situation of power supply in Nigeria for some obvious reasons which will be highlighted later 
(Ajanaku 2007).

To further demonstrate its commitment towards provision of electricity, the Federal government in 2007 awarded the construction of 2,600MW Mambilla plateau hydropower station to Chinese company, Gezhouba Group Corporation, at the cost of $\$ 1.46$ billion. The Mambilla station is part of Nigeria' National Integration Power Plant (NIPP). This project is one of the targets set by government in August 2003 to, among others, establish a sustainable electric power industry, develop capacity to reliable transmit and distribute the increased generation and develop a medium term investment plan for the sector.

Table 4: Federal Government Power Projects in the Niger Delta

\begin{tabular}{|l|l|l|l|l|}
\hline S/ $\boldsymbol{N}$ & Power station & $\begin{array}{l}\text { State } \\
\text { location }\end{array}$ & Units & $\begin{array}{l}\text { Total Output } \\
(\mathbf{M W})\end{array}$ \\
\hline 1 & $\begin{array}{l}\text { Odukpani, } \\
\text { Calabar }\end{array}$ & Cross River & 5 & 561 \\
\hline 2 & Egbema & Imo & 3 & 338 \\
\hline 3 & Ihovobor & Edo & 4 & 451 \\
\hline 4 & Gbarian/Ubie & Bayelsa & 2 & 225 \\
\hline 5 & Sapele & Delta & 4 & 457 \\
\hline 6 & Omoku & Rivers & 2 & 230 \\
\hline 7 & $\begin{array}{l}\text { Ikot } \\
\text { (ALSCON) }\end{array}$ & $\begin{array}{l}\text { Abom } \\
\text { Total Output }\end{array}$ & 3 & 300 \\
\hline
\end{tabular}

Source: Atser (2007) and Agbo (2007).

Other projects of NIPP as presented on Table 4 are; Odukpani, Cross River State, 561MW; Egbama, Imo State, 338MW; Ihovobor, Edo State, 451MW; Gbarian/Ubie, Bayelsa State 225MW; Sapele, Delta State, 451MW; Omoku, Rivers State, 230MW and Ikot Abasi, Akwa Ibom State, 300 MW (Agbo 2007; Atser 2007).

With Power Reform Act already passed into law by the National Assembly and accented by the erstwhile President Obasanjo in 2005, the former National Electric Power Authority was renamed Power Holding Company of Nigeria (PHCN). With this arrangement it was 
expected that by end of 2007 PHCN would have been broken up into 18 companies in a takeover that was expected involve private sector in the generation, transmission and distribution of electricity and further improve on the performance of the sector. The offshoot companies of the PHCN would be made up of one transmission company, six power generation companies and eleven distribution companies (Chiedozie, 2007), although this arrangement has been reversed by the present administration in 2008 .

Table 5: Electricity Generation and Consumption in Nigeria

\begin{tabular}{|l|l|l|l|l|}
\hline Year & $\begin{array}{l}\text { Installed } \\
\text { Capacity } \\
\text { (MW) }\end{array}$ & $\begin{array}{l}\text { Total } \\
\text { Generation(MW } \\
\text { per hour) }\end{array}$ & $\begin{array}{l}\text { Capacity } \\
\text { Utilized } \\
\text { (percent) }\end{array}$ & $\begin{array}{l}\text { Proportion of Total } \\
\text { Generation } \\
\text { Consumed }\end{array}$ \\
\hline 1997 & 4548.6 & 1839.8 & 40.4 & 54.9 \\
\hline 1998 & 4548.6 & 1724.9 & 37.9 & 56.4 \\
\hline 1999 & 5580.0 & 1859.8 & 33.3 & 47.5 \\
\hline 2000 & 5580.0 & 1738.3 & 31.2 & 58.5 \\
\hline 2001 & 6180.0 & 1689.9 & 27.5 & 65.4 \\
\hline 2002 & 6180.0 & 2237.3 & 36.2 & 56.8 \\
\hline 2003 & 6130.0 & 6180.0 & 38.8 & 63.4 \\
\hline 2004 & 6130.0 & 2763.6 & 45.1 & 66.1 \\
\hline 2005 & 6886.6 & 2779.3 & 40.5 & 67.4 \\
\hline
\end{tabular}

Source: Central Bank of Nigeria (2007)

Electricity generation and consumption in Nigeria as presented on Table 5 shows that the installed capacity rose from 4548.6 MW in 1997 to 5580.0 MW in 2000. In 2002, the installed capacity increased to 6180.0MW but fell to 6130.0 in $2004 \mathrm{MW}$ and rose to 6886.6 MW in 2005. While total generation fell from 1839.8 MW per hour in 1997 to 1724.9.3 MW per hour in 1998 but rose to 1859.8 MW per hour in 1999 and fell to $1738.3 \mathrm{MW}$ per hour and 1689.9MW per hour in 2000 and 2001 respectively. Total generation rose to 2237.3 MW per hour in 2002, 6180.0 MW per hour in 2003, fell to 2763.6 MW per hour in 2004 and stood at 2779.3 MW per hour in 2005. The capacity utilized fell from 40.4percent in 1997 to 27.5percent in 2001 but increased to 36.2percent in 2002, 38.8percent in 2003, 45.1percent in 2004 and 40.5 percent in 2005. The proportion of total generation consumed rose from 54.9 percent in 1997 to 56.4 percent in 1998 , fell to 47.5 percent in 1999 but rose to 65.4percent, 
fell to 56.8 percent in 2002 and increased further to 63.4 percent, 66.1percent and 67.4 percent in 2003, 2004 and 2005 respectively. We can now deduce that NEEDS has small impact on the power sector.

\section{Effect of the Power Sector Performance on the Private Sector}

Infrastructure is conceptually perceived by Social Scientists from two interrelated dimensions. These are the social and economic dimensions, the economic infrastructural sub sector embraces a group of hard-core economic activities which are relate to provision of transportation, energy and power etc. (Ayodele and Falokun, 2003). Power indeed is a strategic sector. Indeed, it represents the most important infrastructure requirement for moving the private sector forward. Infrastructures needs cut across sectors and are central to economic development especially the power sector. (National Planning Commission, 2004)

United Nations Industrial Development Organization (UNIDO) survey in 2001 showed that poor or near absence of physical infrastructure was identified as number one problem of manufacturers Surveys conducted showed that manufacturers generated about 72 percent of total power required to run their factories. In extreme cases, some companies operate independent of PHCN. In buttressing the above report, a survey conducted in Lagos showed that the British American Tobacco (BAT) Plc spent about N67.5 million in 2005 on diesel and maintenance of its private power generation plant. Dunlop Nigeria Plc similarly spent N96 million on annual average, while West African Portland Cement spent N90million on the average. Others are Friestland Foods Plc: N50 million; Nigerite Plc: N36millionand Cadbury Nigeria Plc: N49 million (Okafor, 2008).

By Manufacturer Association of Nigeria's statistics, nine companies within its fold spent a total sum of N69.5 billion to generate their power (Odiaka 2006; Oke 2006). Against the backdrop of the epileptic power supply and the desire of the companies to remain in the business, some multinational companies have devised other alternative sources of power generation. In the recent times quite a number of multinational companies operating in Nigeria generate own power through Independent Power Project (IPP) (Udeajah 2006).

Goods produced in Nigeria are uncompetitive because of the high cost of production which is caused by interrupted supply of electricity. The main thrust has been on the cost of spare parts for maintenance of generators and the rising cost of AGO (Diesel). Hence the power sector does not meet the needs of the average investor, thereby inhibiting investment and increasing the cost of doing business. These adversely affect the growth of private sector in the country (Manufacturer Association of Nigeria, 2005).

\section{Challenges and the Way Forward}

According to Manufacturer Association of Nigeria (2005), National Planning Commission (2004) and Akewushola (2002), Most of the principal challenges confronting the power sector in Nigeria are as include:

- Federal government funding to the sector decreased continually between 1980 and 2000 . 
- Inadequate generation capacity

- Poor equipment selection and rationalization increase the cost of maintenance and spare parts

- Inadequate Transmission capacity

- Inadequate Distribution capacity

- Inefficient bill collection system

- Vandalization of facilities

- High level of suppressed demand.

- Low water levels during dry seasons

- Disruption in fuel supply to power stations

Having examined various challenges confronting the power sector in Nigeria, we shall now be looking at suggested plans for removal of the perceived challenges in the power sector, these are:

- Expedite the implementation of the electric power sector reform programme

- Generate 10,000 MW a day, from existing plants, new host generation, and reasonably priced independent power plants.

- Develop the capacity to transmit and distribute the higher level of generation.

- Explore alternative energy sources, such as coal, solar power, wind power, and hydropower.

- Renew attention to the question of electricity tariffs.

- Deregulate the power sector to allow increased private sector participation (PublicPrivate Partnership in virtually all aspects including generation, transmission and distribution seems to be the better option now rather than outright privatization).

- Funding of the power sector in the short term by the last administration should be continued in order to sustain the rehabilitation effort

- Associated gas should be adopted as the primary energy for industrialization and the price should be made attractive.

- An extensive metering programme which has begun, with a view to metering all customers within the next two to three years especially the prepaid metres should be their priority

- The government should consider forming a special security unit for policing power installations

- Establishing a rural electrification agency and fund (National Planning Commission, 
2004)

- Moreover, there is the need to re-orientate PHCN's personnel to work in parastatal that is commercially driven and consumer probity, productivity and efficiency and sanction reoccurring anti- customer behaviours.

- In addition, PHCN is one of the hotbeds of corruption in Nigeria, hence the need to establish anti-corruption and transparency units in the parastatal so that the activities of corrupt officials will be reduced to the barest minimum

- Also members of the public should be sensitised to desist from offering bribes/ inducement to the PHCN staff as a way of securing favours or accelerated service (Okafor, 2008).

\section{Summary and Conclusion}

The paper has attempted to examine different areas of private sectors such as Agricultural, Mining and Quarrying, Manufacturing, Utilities, Post and Telecommunication, Transportation, Banks and other financial institutions were touched using the GDP by economic activity (percentage distribution) for analysis from 2001 to 2007. The NEEDS reform was examined to ascertain whether or not the private sector was actually given the attention it deserves. An overview of power supply in Nigeria was discussed. Also, the effect of power sector on private sector was considered and challenges of the sector and the way forward were discussed.

There is no doubt that serious improvement in the power sector is a pre-requisite for private sector growth in any economy and that of Nigeria is not difference because it could significantly reduce the cost of doing business and improve competitiveness which will definitely make the private sector economy to thrive.

The expectation was that NEEDS reforms will transform the power sector into one led by the private sector, with role of government primarily in policy formulation and regulation. However, the implementation of the NEEDS reforms had not been able to eliminate generation deficits; rehabilitate, reinforce, and expand transmission and distribution networks; impose payment and collection discipline; and increase rural access to electricity, using grid and off-grid approaches, strengthen the basis for private sector growth including by improving power and transport infrastructure. There is therefore the need to put concerted effort to generate adequate power supply to enable the private sector thrives and serves as engine of growth in Nigeria. 


\section{References}

Adegbamigbe, A. ( 2007), Obasanjo's Legacies. The News, Vol. 28 No. 21, June 9, 2007 pp. 68-70.

Agbo, A. (2007), Ending the Power Nightmare. TELL, May, 2007 pp. 28-31 cited in Okafor,E. E.(2008)

Ajanaku, L. (2007), Battling with Darkness. TELL (Special Edition), May 21, 2007 pp. 31-33.

Akewushola, R.O.(2002) : Structure of the Nigerian Economy, Supark International Limited, Lagos

Akpan ,I. ( 2005), Deregulating the Nigeria Power Sector: The Case of Privatization South-South Journal of Culture and Development, 7(1): 87- 108.

Atser, G. (2006),Nigeria, others have less than 25percent access to electricity -World Bank. The Punch, November 19, 2006 pp .28. cited in Okafor,E. E.(2008)

Atser, G. (2007). Chinese firm set for Mambilla. The Punch, April 4, 2007 pp.63. cited in Okafor,E. E.(2008)

Ayodele, A.S. and Falokun, G.O.(2005), The Nigerian Economy- Structure and Pattern of Development; Printoteque, Lagos.

Central Bank of Nigeria (2006), Statistical Bulletin Vol. 17, December, pp. 124. Abuja: Central Bank of Nigeria Publication.

Central Bank of Nigeria (2007), Statistical Bulletin Vol. 18, December, pp. 137and 172. Abuja: Central Bank of Nigeria Publication.

Chiedozie, I. (2007), Obasanjo orders reduction of power firms. The Punch, April 11, 2007 pp. 56.

Federal Government of Nigeria( 2004), A one-day Focused Group Consultation Workshop on National Economic Empowerment and Development Strategy, Office of the Economic Adviser to the President, Abuja, Nigeria, 172 pp.

Federal Office of Statistics (2004), Nigeria Statistics Fact Sheets

Lohor, J. and O. Ezeigbo (2006), Nigeria population is $140 \mathrm{~m}$. Thisday December 30 2006 pp 14.

Makoju, J. (2002), The 2002 Project Plan: Why we are bent on network Expansion NEPA Review Oct - Dec., 2002 pp.12-14.

Manufacturer Association of Nigeria (2005); Private sector / consumer perspective in the power sector/Energy sector- Post-Electric Power sector Reform Act, Being the paper presented by the President of M.A.N. at the National Workshop on the Electric power sector Reform(EPRS) Act 2005 Held at Sheraton Hotel \& Tower, Abuja. April 12, 2005. 


\section{Macrothink}

National Planning Commission (NPC), Nigeria (2004). The National Economic Empowerment and Development Strategy (NEEDS). NPC, Nigeria

Nwaoshai, J. ( 2006), Healthy Power Sector will create jobs in the Telecom industry. Vanguard, October, 25, pp. 43.

Odiaka, P. ( 2006), Power Sector reforms: Still a reign of blackout. The Guardian, August 24, 2006 pp. 15.

Ogumodede, O.B. (2005), Consumers Expectations on Service delivery of PHCN: A Study I in Lagos and Ibadan Metropolis. MBA Thesis (unpublished) Owerri: Imo State University.

Okafor,E. E.(2008); Development Crisis of Power Supply and Implications for Industrial Sector in Nigeria Studies Tribes Tribals Vol 6. No. 2

Oke, B. ( 2006), TUC Rejects Increase in Electricity Tariff. The Punch, February 22, 2006 pp. 32.

Oloja, M. and F. Oretade (2006), Nigeria's population now 140m. The Guardian. December 30, 2006 pp. 1-2.

Udeajah, G. (2006), Industrial firms lose N38 to power outage. The Guardian, August 24, 2006 pp. 29.

UNDP, (2001), Human Development Report Nigeria. Oxford: Oxford University Press 